\title{
PERSEPSI MAHASISWA AKUNTANSI MENGENAI FAKTOR FAKTOR YANG MEMPENGARUHI DALAM MEMILIH PROFESI SEBAGAI AKUNTAN
}

\author{
The perception of Accounting Undergraduate Students in the Factors That Influence the \\ Choices of Profession as Accountant
}

\author{
Wahyu Suhendro ${ }^{1}$; Ahmad Jibrail ${ }^{1}$; Fitriah Permatacita ${ }^{2}$ \\ ${ }^{1}$ Program Studi Akuntansi, Fakultas Ekonomi dan Bisnis Universitas Teknologi Sumbawa \\ ${ }^{2}$ Program Studi Ekonomi Pembangunan, Fakultas Ekonomi dan Bisnis Universitas Teknologi Sumbawa \\ *)E-mail : Wahyusuhendro94@gmail.com
}

\begin{abstract}
This research aims to identify the perception of Accounting undergraduate students in choosing a profession as accountant based on the indicators of salary, professionalism acknowledgement, social values, work environment, job market consideration and personality. In addition, it also aims to know the most and the less favourite profession of the students. The method of this research is descriptive-quantitative with random sampling method to get 71 respondents. The results show that factors influencing carreer choice as an accountant is salary, professionalism acknowledgement, job market and personality. Meanwhile, the social values and work environment factors are less considered by the students in choosing their carreer.
\end{abstract}

Keywords: perception, accounting students, accountant profession

\begin{abstract}
ABSTRAK
Penelitian ini bertujuan untuk mengetahui bagaimana persepsi mahasiswa akuntansi dalam memilih profesi sebagai akuntan ditinjau dari gaji, pengakuan profesionalitas, nilai nilai sosial, lingkungan kerja, pertimbangan pasar kerja dan personalitas. Selain itu juga untuk mengetahui profesi yang paling diminati dan kurang diminati oleh mahasiswa. Metode penelitian yang digunakan adalah dekriptif kuantitatif, pengambilan sampel menggunakan metode random sampling dengan jumlah responden sebanyak 71 orang. Hasil penelitian menunjukan bahwa faktor faktor yang mempengaruhi dalam pemilihan karir sebagai akuntan adalah gaji, pengakuan profesionalitas, pasar kerja dan personalitas sementara faktor nilai sosial dan lingkungan kerja kurang dipertimbangkan oleh mahasiswa dalam memilih profesi.
\end{abstract}

Kata kunci : Persepsi, mahasiswa akuntansi, profesi akuntansi

\section{Pendahuluan}

Seiring dengan perkembangan dunia bisnis yang semakin maju, ilmu akuntansi berkembang dengan sangat baik, peranan seorang akuntan menjadi sangatlah penting dalam perkembangan ini. Di Indonesia masih menyediakan peluang kerja yang sangat besar bagi para lulusan akuntansi yang ingin berkarir sebagai akuntan publik, akuntan pemerintah, akuntan perusahaan maupun akuntan pendidik. Oleh karena itu tidaklah mengherankan jika pemerintah mengeluarkan regulasi untuk mengatur profesi ini.

Berdasarkan UU No. 5 Tahun 2011, seluruh lulusan sarjana dari berbagai macam jurusan dapat menjadi seorang akuntan, yakni akuntan publik manakala sudah mengikuti ujian sertifikasi secara khusus yang dilaksanakan oleh pemerintah. Undang- Undang ini berisikan ruang lingkup jasa akuntan publik, perizinan akuntan publik dan KAP, hak, kewajiban, dan larangan bagi Akuntan Publik dan KAP, kerja sama antar-Kantor Akuntan Publik (OAI) dan kerja sama antara KAP dan Kantor Akuntan Publik Asing (KAPA) atau Organisasi Audit Asing (OAA), Asosiasi Profesi Akuntan Publik, Komite Profesi Akuntan Publik, pembinaan dan pengawasan oleh Menteri, sanksi administratif dan ketentuan pidana.

Pada awalnya, mahasiswa jurusan akuntansi adalah mahasiswa yang memiliki kesempatan besar untuk 
langsung melanjutkan karir atau profesi sebagai akuntan, namun setelah adanya regulasi atau peraturan dan kebijakan yang ditetapkan pemerintah, mahasiswa dihadapkan dalam beberapa pilihan untuk menjadi seorang akuntan. Dengan berbagai macam persyaratan dan mekanisme yang harus dilalui untuk menjadi seorang akuntan, sedikit banyak mempengaruhi persepsi seorang mahasiswa untuk menjadi seorang akuntan. Waktu dan biaya yang sangat besar menjadi salah satu faktor yang menghambat mahasiswa untuk menjadi seorang akuntan.

Seperti yang telah disebutkan sebelumnya terdapat berbagai jenis karir yang dapat dijalankan oleh lulusan akuntansi yaitu akuntansi publik, akuntansi pemerintahan, akuntansi perusahaan dan akuntansi pendidik, dalam memilih karir yang akan dijalaninya, mahasiswa akuntansi memiliki berbagai pertimba untuk memilih karir apa yang akan dijalaninya. Fакıигfaktor yang mempengaruhinya terdiri dari penghargaan finansial atau gaji, pengakuan profesional, nilai-nilai sosial, lingkungan kerja, pertimbangan pasar kerja, dan personalitas.

Faktor-faktor yang mempengaruhi pemilihan karir mahasiswa dan jenis karir yang akan mereka jalani merupakan hal yang menarik untuk diteliti karena dengan diketahuinya pilihan karir yang diminati mahasiswa, maka dapat diketahui mengapa seseorang memilih karir tersebut (Rahayu, 2003).

Adapun faktor faktor yang yang mempengaruhi pemilihan karir diantaranya adalah Penghargaan finansial atau gaji, Lingkugan kerja, Sifat pekerjaan, tingkat persaingan dan banyaknya tekanan kerja.

Perumusan masalah di sini dimaksudkan untuk menghindari kesalahan-kesalahan dalam permasalah yang akan dibahas. Sehingga permasalahan dapat dirumuskan sebagai berikut:

1. Bagaimana persepsi mahasisiwa dalam memilih profesi sebagai akuntan. ?

2. Profesi manakah yang paling diminati dan kurang diminati oleh mahasiswa. ?

\section{Metode Penelitian}

Penelitian ini menggunakan metode pendekatan kuantitatif, dengan tipe deskriptif. Metode pendekatan kuantitatif menurut sugiyono (2012) adalah metode penelitian yang berlandaskan pada filsafat positivesme, digunakan untuk meneliti pada populasi atau sampel tertentu, pengumpulan data menggunakan instrumen penelitian, analisis data bersifat kuantitatif/statistik dengan tujuan untuk menguji hipotesis yang telah ditetapkan.

Variabel penelitian merupakan variabel yang digunakan guna keperluan penelitian. Variabel penelitian yang digunakan dalam penelitian ini adalah gaji pengakuan profesional, nilai-nilai sosial, lingkungan kerja, pertimbangan pasar kerja dan personalitas sebagai variabel bebas. Sedangkan untuk variabel terikat yang digunakan adalah akuntansi publik, akuntansi perusahaan, akuntansi pendidik, dan akuntansi pemerintahan.

Populasi adalah wilayah generalisasi yang terdiri atas : obyek/subyek yang mempunyai kualitas dan karakteristik tertentu yang ditetapkan oleh peneliti untuk dipelajari dan kemudian ditarik kesimpulannya. (sugiyono, 2015). Populasi yang dipilih dalam penelitian ini adalah semua mahasiswa aktif program studi Akuntansi Fakultas Ekonomi Dan Bisnis, Universitas Teknologi Sumbawa yaitu sebanyak 240 mahasiswa.

Sampel dalah bagian dari jumlah dan karakteristik yang dimiliki oleh populasi tersebut. ( sugiyono, 2015). Metode pengambilan sampel dalam penelitian ini menggunakan simple random sampling, Simple random sampling Menurut Kerlinger (2006) adalah metode penarikan dari sebuah populasi atau semesta dengan cara tertentu sehingga setiap anggota populasi atau semesta tadi memiliki peluang yang sama untuk terpilih atau terambil.

Penentuan jumlah sampel dalam penelitian ini mengunakan rumus slovin (sugiyono, 2006)

$$
\mathrm{n}=\frac{N}{1+N e^{2}}
$$

dimana:

$\mathrm{n}=$ jumlah sampel

$\mathrm{N}=$ jumlah dari populasi

$\mathrm{e}=$ tingkat signifikansi ( $10 \%)$

$\mathrm{n}=\frac{N}{1+N e^{2}}=>\frac{240}{1+\left(240(0.1)^{2}\right)}=70,58 \rightarrow 71$

Data yang diperlukan untuk menganalisis penelitian ini dapat diperoleh dari Data Primer, yakni data yang diperoleh langsung dari sumber atau objek peneliti. Data primer ini diperoleh melalui kuesioner. Angket atau kuesioner merupakan tehnik pengumpulan data yang dilakukan dengan cara memberi seperangkat pertanyaan atau peryataan tertulis kepada responden untuk dijawab, (Sugiyono,2008) sedangkan menurut Arikunto (2006) angket adalah pernyataan tertulis yang digunakan untuk memperoleh informasi dari responden untuk informasi dari responden dalam arti laporan tentang pribadi atau hal yang ia ketahui. Kuisioner yang digunakan dalam penelitian ini menggunakan pertanyaan tertutup karena responden tinggal memberih tanda pada jawaban yang mereka anggap benar.

Metode pengumpulan data yang dilakukan dalam penelitian ini adalah mendatangi responden secara langsung, kemudian menyebarkan daftar pertanyaan 
atau kuisioner kepada mahasiswa dan mahasiswi akuntansi Universitas Teknologi Sumbawa. Daftar pertanyaan yang digunakan adalah pertanyaan terstruktur dan responden tinggal memberi tanda $(\sqrt{ })$ pada jawaban yang dipilih, kemudian responden langsung mengembalikan daftar pertanyaan setelah diisi.

Metode analisis data dalam penelitian ini dilakukan dengan cara menganalisis statistic diskriptif dan menguji kualitas data.

\section{Analisis Statistik Diskriptif}

Statistik deskriptif digunakan untuk mengetahui deskripsi tentang karakter variabel-variabel gaji, pengakuan professional, nilai sosial, lingkungan kerja, pertimbangan pasar kerja dan personalitas dengan melihat table statistik deskriptif yang menunjukkan angka kisaran teoritis dan kisaran aktual, rata rata, dan standar deviasi.

2. Uji Kualitas Data

\section{a. Uji Normalitas}

Untuk menguji kenormalan data dilakukan dengan serangkaian pengujian yang bertujuan untuk membantu peneliti dalam menentukan distribusi normal. b. Uji validitas

Uji validitas digunakan untuk mengukur sah atau valid tidaknya suatu kuesioner,suatu kuesioner dinyatakan valid jika pertanyaan pada kuesioner mampu untuk mengungkapkan sesuatu yang akan diukur oleh kuesioner tersebut (Ghozali, 2005).

c. Uji Reliabilitas

Reliabilitas berhubungan dengan konsistensi. Menurut Sumarni dan Wahyuni (2006), reliabilitas menunjukkan sejauh mana suatu alatukur konsisten atau memiliki kemantapan dalam penggunaannya, baik ditinjau dari waktu ke waktu maupun dari kondisi satu dengan kondisi yang lain.

\section{Hasil dan Pembahasan}

\section{A. Statistik Deskriptif}

Analisis statistik deskriptif dilakukan dengan tujuan untuk mengetahui nilai nilai variabel dalam penelitian ini. Berikut ini adalah tabel deskriptif yang menerangkan nilai maksimum, nilai minimum, mean (dalam hal ini nilai mean dari keseluruhan responden terhadap masing masing variabel) dan standar deviasi variabel penelitian:

Tabel 1. Descriptive Statistics

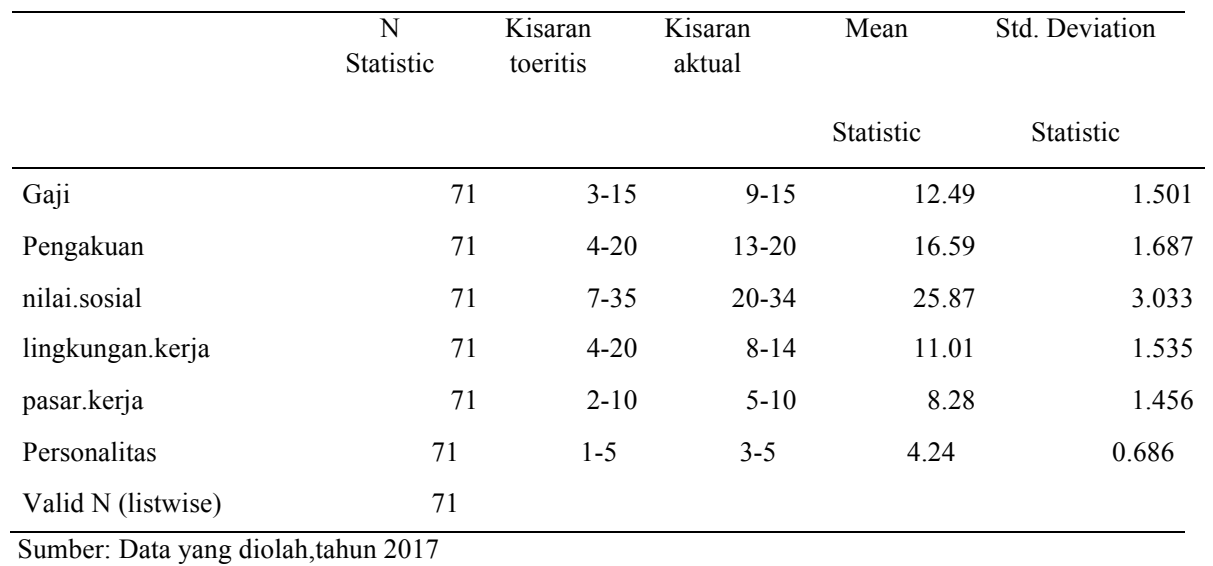

Table diatas menggambarkan deskripsi variabel variabel dalam penelitian ini secara statistik. Kisaran teoritis menjelaskan kisaran yang seharusnya antara skor jawaban paling rendah dengan skor jawaban paling tinggi berdasarkan jumlah butir dan jumlah skala interval dalam kuesioner.Kisaran aktual menjelaskan skor jawaban responden penelitian terendah dan tertinggi. Mean merupakan cara yang paling umum digunakan untuk mengukur nilai sentral suatu distribusi data berdasarkan nilai rata-rata yang dihitung dengan cara membagi nilai hasil penjumlahan sekelompok data yang diteliti. Sedangkan standar deviasi merupakan varian untuk mengukur dispersi dengan nilai dikuadratkan (Nur et al. 2002).

B. Jenis Karir Responden

Deskripsi jenis karir yang diinginkan oleh responden akan disajikan didalam tabel berikut:

Tabel 2. Jenis Karir yang diinginkan responden

\begin{tabular}{lll}
\hline Jenis karir & frekuensi & $\%$ \\
\hline Akuntan public & 15 & 21,13 \\
Akuntan perusahaan & 22 & 30,99 \\
Akuntan pendidik & 4 & 5,63 \\
Akuntan pemerintahan & 30 & 42,25 \\
\hline Total & 71 & 100 \\
\hline Sumber: Data primer diolah, 2017 &
\end{tabular}


Berdasarkan tabel di atas jenis karir yang diinginkan oleh responden dalam penelitian ini ialah sebagian besar responden menginginkan karir sebagai akuntan perusahaan yakni sebanyak 30 responden atau sebesar $42,25 \%$ dari keseluruhan sampel. Selanjutnya diikuti oleh responden yang mengiginkan karir sebagai akuntan perusahaan sebanyak 22 responden atau 30,99\% .15 responden atau $21,13 \%$ menginginkan karir sebagai akuntan perusahaan dan sebanyak 4 responden atau 5,63 menginginkan karir sebagai akuntan pendidik. Pengalokasian BTKL paving block

\section{Uji Normalitas}

Untuk menguji kenormalan data dilakukan dengan pengujian Skewness dan Kurtosis, untuk mengetahui apakah variabel berdistribusi normal atau tidak maka sebelumnya dilakukan perhitungan nilai statistik skewness dan Kurtosis dengan rumus berikut ini :

$$
\begin{array}{ll}
\text { Menghitung zskew : } & \frac{k-O}{\sqrt{24 / N}} \\
\text { Menghitung Zkurt : } & \frac{S-O}{\sqrt{6 / N}}
\end{array}
$$

Tabel 3. Perhitungan Biaya Overhead Pabrik Periode mei 2017

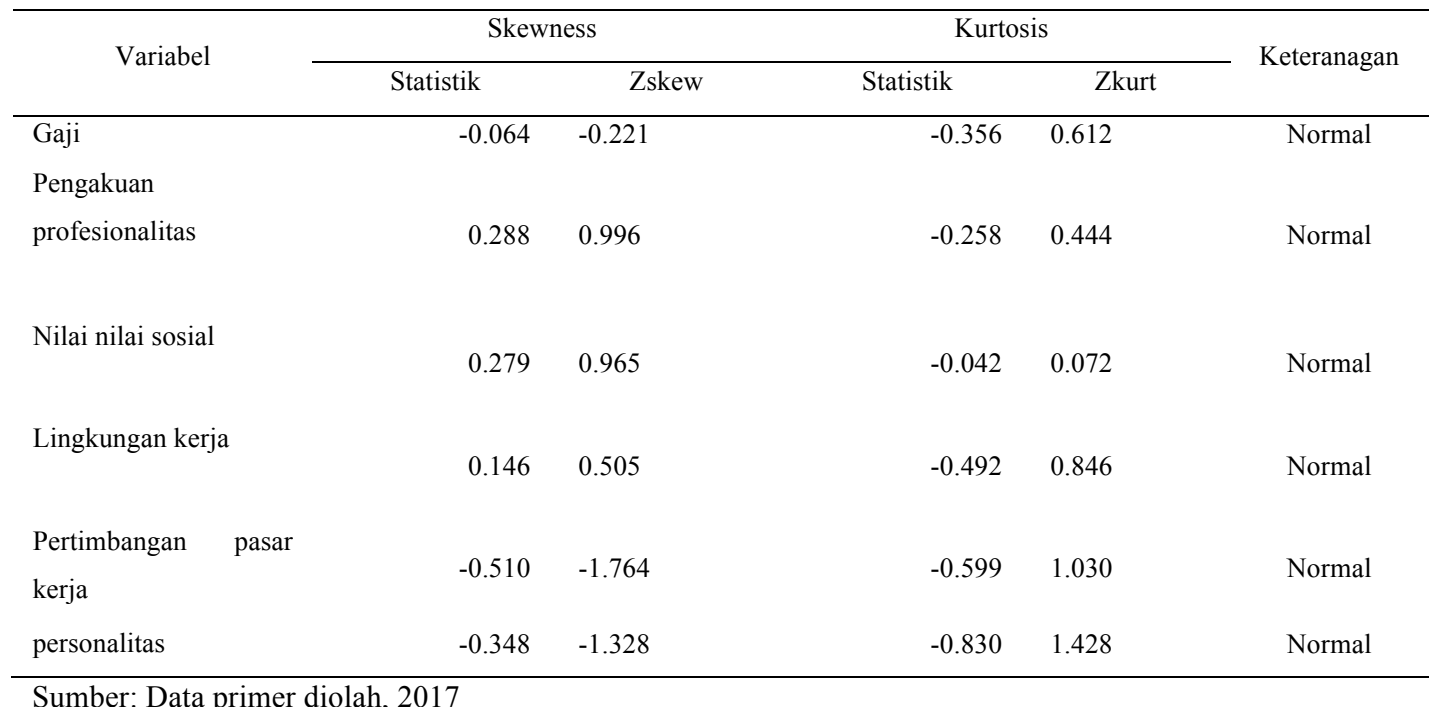

Tabel diatas menunjukan hasil uji Skewness dan Kurtosis bahwa semua variabel dalam penelitian ini memiliki nilai Skewness dan Kurtosis $\pm 1,96$, sehingga dapat disimpulkan bahwa semua variabel berdistribusi normal (Ghozali, 2005.)

D. Uji Kualitas Data

1. Uji Validitas

Uji validitas digunakan untuk mengukur sah atau valid tidaknya suatu kuesioner,suatu kuesioner dinyatakan valid jika pertanyaan pada kuesioner mampu untuk mengungkapkan sesuatu yang akan diukur oleh kuesioner tersebut (Ghozali, 2005). Uji validitas dikakukan dengan menggunakan rumus korelasi, selengkapnya dapat dilihat pada tabel 4 .

Dari tabel tersebut dapat dilihat bahwa semua indikator mampu menjelaskan suatu variabel. Hal ini dapat diidentifikasikan dari nilai korelasi yang lebih besar dari nilai $\mathrm{r}$ tabel yaitu $\mathrm{df}=\mathrm{N}-2=69$ atau dapat dilihat pada distribusi nilai $r$ tabel yaitu 0.2303 .

\section{Uji Reliabilitas}

Uji realibitas merupakan alat untuk mengukur suatu kuesioner yang merupakan indikator dari variabel. Suatu kuesioner dikatakan reliabel atau handal jika jawaban seseorang terhadap pernyataan adalah konsisten dari waktu ke waktu. Dalam penelitian ini pengujian dilakukan terhadap 71 responden. Pengujian reabilitas menggunakan rumus alpha dengan bantuan SPSS 20. Selengkapnya dapat dilihat pada tabel 5.

Dari tabel 5 tersebut dapat dilihat bahwa semua variabel memiliki nilai koefisien alpha yang lebih besar dari r.tabel dengan jumlah sampel sebanyak 71 responden dan tingkat signifikan $0.5 \%$ atau 0.2303 , sehingga bisa dikatakan semua variabel yang digunakan dalam penelitian ini adalah reliabel. 
Tabel 4. Hasil Uji Validitas

\begin{tabular}{|c|c|c|c|}
\hline No & Korelasi & r.tabel & Keterangan \\
\hline & \multicolumn{3}{|c|}{ Penghargaan finansial/Gaji } \\
\hline 1 & 0,719 & 0.2303 & Valid \\
\hline 2 & 0.555 & 0.2303 & Valid \\
\hline \multirow[t]{2}{*}{3} & 0.705 & 0.2303 & Valid \\
\hline & \multicolumn{3}{|c|}{ Pengakuan profesionalitas } \\
\hline 1 & 0.435 & 0.2303 & Valid \\
\hline 2 & 0.604 & 0.2303 & Valid \\
\hline 3 & 0.632 & 0.2303 & Valid \\
\hline \multirow[t]{2}{*}{4} & 0.534 & 0.2303 & Valid \\
\hline & \multicolumn{3}{|c|}{ Nilai nilai social } \\
\hline 1 & 0.385 & 0.2303 & Valid \\
\hline 2 & 0.557 & 0.2303 & Valid \\
\hline 3 & 0.477 & 0.2303 & Valid \\
\hline 4 & 0.608 & 0.2303 & Valid \\
\hline 5 & 0.468 & 0.2303 & Valid \\
\hline 6 & 0.537 & 0.2303 & Valid \\
\hline \multirow[t]{2}{*}{7} & 0.534 & 0.2303 & Valid \\
\hline & \multicolumn{3}{|c|}{ Lingkungan kerja } \\
\hline 1 & 0.692 & 0.2303 & Valid \\
\hline 2 & 0.736 & 0.2303 & Valid \\
\hline \multirow[t]{2}{*}{3} & 0.437 & 0.2303 & Valid \\
\hline & \multicolumn{3}{|c|}{ Pertimbangan pasar kerja } \\
\hline 1 & 0.859 & 0.2303 & Valid \\
\hline \multirow[t]{2}{*}{2} & 0.766 & 0.2303 & Valid \\
\hline & & Persona & \\
\hline 1 & 1.000 & 0.2303 & Valid \\
\hline
\end{tabular}

Sumber: Data primer diolah, 2017

Tabel 5. Hasil Uji Reliabilitas

\begin{tabular}{lll}
\hline \multicolumn{1}{c}{ Variabel } & r.tabel & Alpha \\
\hline Gaji & 0.2303 & 0.364 \\
Pengakuan & 0.2303 & 0.249 \\
profesionalitas & & \\
Nilai nilai sosial & 0.2303 & 0.515 \\
Lingkungan kerja & 0.2303 & 0.248 \\
Pertimbangan pasar & 0.2303 & 0.549 \\
kerja & 0.2303 & 1.000 \\
Personalitas &
\end{tabular}

Sumber: Data primer diolah, 2017

E. Pembahasan

1. Penghargaan Finansial / Gaji

Hasil penelitian ini menunjukkan bahwa terdapat perbedaan pandangan atau persepsi mahasiswa akuntansi dalam mimilih karir dilihat dari faktor pengharagaan finansial atau gaji. Dengan demikian hasil penelitian ini menyetujui penelitian rahayu (2003) yang menyatakan adanya perbedaan pandangan mahasiswa dalam memilih karir. Faktor gaji paling berpengaruh pada pemilihan karir sebagai akuntan perusahaan dan akuntan pendidik yaitu dengan nilai mean masing masing 4,300 dan 4,250. Dibanding dengan akuntansi pemerintahan dan akuntansi publik dengan nilai mean masing masing sebesar 4,100 dan 4,066.

Tabel 6. Persepsi responden tentang faktor gaji

\begin{tabular}{lcccc}
\hline \multicolumn{5}{c}{ Tabel Mean Indikator Gaji } \\
\hline Karir & $\mathrm{N}$ & $\mathrm{P} 1$ & $\mathrm{P} 2$ & $\mathrm{P} 3$ \\
Ak.Pendidik & 4 & 3.750 & 4.500 & 4.500 \\
Ak.Publik & 15 & 3.866 & 4.333 & 4.000 \\
Ak.Perusahaan & 22 & 4,000 & 4.681 & 4.227 \\
Ak.Pemerintahan & 30 & 3.800 & 4.433 & 4.066 \\
Rata Rata Total & 71 & 3.900 & 4.490 & 4.100 \\
\hline
\end{tabular}

Sumber: Data primer diolah

Penghargaan finansial dianalisis dengan menggunakan tiga pertanyaan yaitu, gaji awal yang tinggi, tersedianya dana pensiun, dan kenaikan gaji yang cepat. Berdasarkan hasil hitung nilai rata rata, indikator yang paling mempengaruhi dalam variabel penghargaan finansial atau gaji ialah indikator kedua yaitu tersedianya dana pensiun, artinya dalam menjalankan suatu karir atau profesi mahasiswa beranggapan bahwa kerir tersebut akan memberikan dana pensiun ketika mereka berhenti dari suatu karir atau profesi.

\section{Pengakuan Profesionalitas}

Hasil penelitian ini juga menunjukkan bahwa adanya perbedaan persepsi mahasiswa dalam memilih karir, dan menyetujui hasil penelitian Rahayu (2003). Pengakuan profesionalitas dipertimbangkan oleh mahasiswa dalam memilih karir hal ini berarti bahwa dalam memilih karir mahasiswa tidak hanya mengharapkan gaji semata, tetapi juga ada keinginan untuk diakui secara profesional.

Faktor pengakuan profesionalitas paling berpengaruh dalam pemilihan karir sebagai akuntan perusahaan dan akuntan publik dengan nilai rata rata masing masing sebesar 4,305 dan 4,132 dibandingkan dengan akuntan pemerintahan dan akuntan pendidik dengan nilai rata rata masing masing sebesar 4,075 dan 3,875. Lebih detail dapat dilihat pada tabel 7.

Berdasarkan hasil perhitungan pada tabel 7 tersebut dapat dilihat bahwa indikator yang paling mempengaruhi dalam variabel pengakuan profesional adalah indikator pertama yaitu lebih banyak memberikan kesempatan untuk berkembang artinya bahwa dalam menjalankan sebuah profesi atau karir mahasiswa menginginkan adanya peningkatan atau perkembangan atas karir yang sedang dijalaninya tersebut. 
Tabel 7. Persepsi responden tentang pengakuan profesionalitas

\begin{tabular}{lcccccc}
\hline & Tabel Mean Indikator Variabel Pengakuan & & \\
\hline Karir & $\mathrm{N}$ & $\mathrm{P} 1$ & $\mathrm{P} 2$ & $\mathrm{P} 3$ & $\mathrm{P} 4$ \\
Ak.Pendidik & 4 & 4.250 & 3.250 & 3.750 & 4.250 \\
Ak.Publik & 15 & 4.400 & 4.466 & 3.466 & 4.200 \\
Ak.Perusahaan & 22 & 4.590 & 4.318 & 4.136 & 3.466 & 4.233 \\
Ak.Pemerintahan & 30 & 4.500 & 4.100 & 4.690 & 4.210 \\
Rata Rata Total & 71 & 4.490 & 4.200 & 3.60 \\
\hline
\end{tabular}

Sumber: Data primer diolah, 2017

\section{Nilai Nilai Sosial}

Hasil penelitian ini menunjukan adanya perbedaan persepsi mahasiswa dalam memilih karir sabagai akuntan, hal ini dapat dilihat dari hasil perhitungan nilai rata rata variabel nilai sosial, dan menolak hasil penelitian rahayu (2003) yang menyatakan bahwa tidak terdapat perbedaan perbedaan pandangan mengenai pemilihan karir yang dilihat dari faktor nilai sosial.

Faktor nilai sosial paling berpengaruh pada pemeilihan karir sebagai akuntan perusahaan dan akuntan pemerintahan yaitu dengan nilai rata rata masing masing
3,778 dan 3,694 dibandigkan dengan akuntan publik dan akuntan pendidik dengan nilai rata rata masing masing sebesar 3,673 dan 3,464.

Tabel 8 merikut memberikan informasi mengenai persepsi responden tentang indikator nilai sosial tersebut. Dapat dilihat dari tabel tersebut bahwa lebih banyak memberikan kesempatan untuk melakukan kegiatan sosial, menjadi indikator paling berngaruh pada variabel nilai nilai sosial, mahasiswa menganggap dalam menjalankan karir atau profesi mereka juga membutukan waktu untuk melakukan kegiatan kegiatan sosial di tengah masyarakat.

Tabel 8. Persepsi responden tentang indikator nilai sosial

\begin{tabular}{|c|c|c|c|c|c|c|c|c|}
\hline \multicolumn{9}{|c|}{ Tabel Mean Indikator Variabel Nilai Nilai Sosial } \\
\hline Karir & $\mathrm{N}$ & $\mathrm{P} 1$ & P2 & P3 & $\mathrm{P} 4$ & P5 & P6 & P7 \\
\hline Ak.Pendidik & 4 & 4.000 & 4.250 & 3.000 & 3.000 & 3.000 & 3.750 & 3.250 \\
\hline Ak.Publik & 15 & 4.000 & 4.200 & 3.600 & 3.533 & 3.333 & 3.600 & 3.200 \\
\hline Ak.Perusahaan & 22 & 4.136 & 4.181 & 4000 & 3.681 & 3.318 & 3.590 & 3.545 \\
\hline \multicolumn{9}{|l|}{ Ak.Pemerintahan } \\
\hline & 30 & 4.266 & 4.166 & 3.666 & 3.366 & 3.166 & 3.766 & 3.466 \\
\hline Rata Rata Total & 71 & 4.150 & 4.180 & 3.720 & 3.500 & 3.240 & 3.700 & 3.400 \\
\hline
\end{tabular}

Sumber: Data primer diolah, 2017

\section{Lingkungan Kerja}

Berdasarkan hasil perhitungan nilai rata rata variabel masing masing jenis karir bahwa terdapat perbedaan pandangan mahasiswa dalam memilih karir ditinjau dari faktor lingkungan kerja, dengan demikian penelitian ini juga menyetujui hasil penelitian rahayu (2003), faktor lingkungan kerja paling berpengaruh dalam pemilihan karir sebagai akuntan perusahaan dan akuntan publik yaitu dengan nilai rarta rata 3,756 dan 3,643 dibandingkan dengan nilai rata rata akuntan pemerintahan dan akuntan pendidik yaitu 3,633 dan 3.583. Lingkungan kerja dianalisa menggunakan tiga pertanyaan yaitu pekerjaan yang rutin, pekerjaan yang lebih atraktif dan, sering lembur, berdasarkan nilai rata rata pada tabel 9 berikut dapat dilihat bahwa indikator yang memiliki nilai tertinggi dalam mempengaruhi variabel lingkungan kerja adalah pekerjaan yang bersifat rutin. 
Tabel 9. Persepsi responden tentang indikator lingkungan kerja

\begin{tabular}{lcccc}
\hline \multicolumn{5}{c}{ Tabel Mean Indikator Variabel Lingkungan Kerja } \\
\hline Karir & $\mathrm{N}$ & $\mathrm{P} 1$ & $\mathrm{P} 2$ & $\mathrm{P3}$ \\
Ak.Pendidik & 4 & 3.250 & 4.000 & 3.500 \\
Ak.Publik & 15 & 3.800 & 3.400 & 3.733 \\
Ak.Perusahaan & 22 & 3.772 & 3.954 & 3.545 \\
Ak.Pemerintahan & 30 & 3.766 & 3.633 & 3.500 \\
Rata Rata Total & 71 & 3.75 & 3.704 & 3.56 \\
\hline
\end{tabular}

Sumber: Data primer diolah, 2017

\section{Pertimbangan Pasar Kerja}

Mengenai pertimbangan pasar kerja, berdasarkan nilai rata rata variabel yang diperoleh dalam penelitian ini dapat dikatakan bahwa terdapat perbedaan pandangan dalam pemilihan karir, sejalan dengan penelitian yang telah dilakukan rahayu (2003). Tabel 10 berikut memberi informasi tentang persepsi responden mengenai pentingnya faktor indikator variabel pasar kerja dalam mempengaruhi keputusan responden dalam memilih profeesei sebagai akuntan.
Tabel tersebut menunjukkan bahwa faktor pertimbangan pasar kerja lebih berpengaruh dalam pemilihan karir sebagai akuntan perusahaan dan akuntan pemerintahan. Faktor pertimbangan pasar kerja dianalisis menggunakan dua pertanyaan yaitu, keamanan kerja yang lebih terjaga (tidak mudah di PHK) dan lapangan pekerjaan yang ditawarkan mudah diketahui atau diakses. Indikator pertama lebih berpengaruh dalam variabel pertimbangan pasar kerja, artinya mahsiswa menginginkan karir atau profesi yang dijalaninya kelak dapat memberikan keamanan kerja atau tidak mudah di PHK.

Tabel 10. Persepsi responden tentang indikator pasar kerja

\begin{tabular}{lccc}
\hline & & Tabel Mean Indikator Variabel Pasar Kerja & P2 \\
\hline Karir & $\mathrm{N}$ & $\mathrm{P} 1$ & 4.000 \\
Ak.Pendidik & 4 & 3.750 & 3.466 \\
Ak.Publik & 15 & 4.066 & 4.318 \\
Ak.Perusahaan & 22 & 4.500 & 4.066 \\
Ak.Pemerintahan & 30 & 4.266 & 4.010 \\
Rata Rata Total & 71 & 4.270 & 4 \\
\hline
\end{tabular}

Sumber: Data primer diolah, 2017

\section{Personalitas}

Secara keselurahan faktor personalitas berpengaruh dalam pengambilan keputusan memilih karir baik sebagai akuntan pendidik, akuntan publik, akuntan perusahaan, maupun akuntan pemerintahan. Mahasiswa menginginkan bahwa karir yang mereka pilih dapat mencerminkan sikap profesionalitas mereka dalam bekerja.

\section{Kesimpulan}

Berdasarkan hasil penelitian mengenai faktor faktor yang mempengaruhi dalam memilih propesi sebagai akuntan bagi mahasiswa akuntansi bahwa faktor faktor yang mempengaruhi dalam memilih profesi sebagai akuntan adalah faktor penghargaan finansial atau gaji, pengakuan profesionalitas, pasar kerja dan personalitas. Sedangkan faktor nilai nilai sosial dan lingkungan kerja tidak terlalu di pertimbangkan di dalam penelitian ini. Karir profesi yang paling diminati oleh mahasiswa adalah sebagai akuntan pemerintahan dan yang kurang diminati adalah sebagai akuntan pendidik.

\section{Saran}

Adapun saran yang diberikan adalah sebagai berikut :

1. Sebaiknya untuk penelitian selanjutnya dapat mengunakan pertanyaan terbuka dan menambahkan wawancara sebagai instrumen penelitian agar diperoleh hasil penelitian yang lebih lengkap.

2. Bagi perguruan tinggi agar dapat meningkatkat kualitas pengajaran sebagai upaya dalam menghasilkan akuntan akuntan yang siap bersaing di dunia kerja. 


\section{Daftar Pustaka}

Akuntan Publik Yang Dituangkan Dalam Undang Undang Republik Indonesia No.5. (2011).

Ahmad, R. (2009). Pengaruh Profitabillitas dan Investmen Opportunity Set Terhadap Kebijakan Dalam Deviden Tunai. ISSN : 1979 Vol.2 No.2.

Ansori, M., \& Pransiska, S. B. (n.d.). Analisis Perbedaan Persepsi Mahasiswa Akuntansi Junior Dan Mahasiswa Akuntansi Senior Terhadap Akuntan Dan Profesi Akuntan Pada Program Sarjana Vokasi Di Kota Batam.

Arikunto. (2006). Prosedur Pendekatan Suatu Pendekatan Praktek. Jakarta: PT. Rineka Cipta.

Asrori, M. (2009). Psikologi Pembelajaran. Bandung: CV. Wacana Prima.

Benny, E. (2006). Pengaruh Motivasi Terhadap Minat Mahasiswa Akuntansi Untuk Mengikuti Pendidikan Profesi Akuntansi (PPAK). Simposium Nasional Akuntansi IX.

Bimo, W. (2004). Pengantar Psikologi Umum. Jakarta.

Departemen Pendidikan Dan Kebudayaan . Kamus Besar Bahasa Indonesia. (1995). jakarta: Balai Pustaka.

Fahriani, D. (2012). Pengaruh Motivasi Terhadap Minat Mahasiswa Akuntansi Untuk Mengikuti Pendidikan Profesi Akuntansi (PPAk). Jurnal Ilmu \& Riset Akuntansi, Vol.1 No.12.

Ghozali, I. (2005). Aplikasi Analisis Multivariate Dengan Program SPSS. Semarang: BP Universitas Diponegoro.

Hansen, \& Mowen. (2006). Akuntansi Manajemen. Jakarta: Salemba Empat.

Kerlinger. (2006). Asas Asas Penelitian Behaviour. Edisi 3 Cetakan 7. Yogyakarta: UGM Press.

Mulyadi. (2002). Auditing . Edisi 6. Jakarta: Salemba Empat.

Novius, A., \& Arifin. (2008). Perbedaan Persepsi Intensitass Moral Mhasiswa Akuntansi Dalam Proses Pembuatan Keputusan Moral ( Studi Survei Pada Mahasiswa S1, Pendidikan Profesi Akuntansi (PPAK) UNDIP. Semarang.

Rahayu, S. (2003). Persepsi Mahasiswa Akuntansi Mengenai Faktor Faktor Yang Mempengaruhi
Pemilihan Karir . Simposium Nasional Akuntansi VI.

Rasmini, N. K. (2007). Faktor Faktor Yang Berpengaruh Pada Keputusan Pemilihan Akuntansi Publik Dan Nonkuntan Publik Pada Mahasiswa. Buletin Studi Ekonomi Vol.12 No.3.

Reality. (2008). Kamus Terbaru Bahasa Indonesia. Reality Publisher.

Regar, M. H. (2003). Kilas Sorot Perkembangan Akuntansi di Indonesia " Akuntansi Indonesia di Tengah Kanca Perubahan". Jakarta: Pustaka LP3ES.

Robbin, S. P. (2006). Prilaku Organisasi. Edisi 10. jakarta: PT Indeks Kelompok Gramedia.

Setiayani, R. (2005). Faktor Faktor Yang Membedekan Mahasiswa Akuntansi Dalam Memilih Profesi Sebagai Akuntan Publik Dan Non Akuntan Publik ( Studi Empiris Pada Mahasiswa Akuntansi Perguruan Tinggi Negeri di Pulau Jawa ). Tesis, Program Studi Magister Sains UNDIP.

Siswoyo, D. (2007). Ilmu Pendidikan. Yogyakarta: UNY Press.

Slameto. (2010). Belajar Dan Faktor Faktor Yang Mempegaruhinya. Jakarta: Rineka Cipta.

Soemarso, S. (2004). Akuntansi Suatu Pengantar. In Edisi 5. Jakarta: Salemba Empat.

Sugiyono. (2006). Metode Penelitian Kuantitatif, Kualitatif, Dan R\&D. Bandung: Alfabeta.

Sugiyono. (2008). Metode Penelitian Dan Bisnis. Bandung: Alfabeta.

Sugiyono. (2012). Memahami Penelitian Kualitatif . Bandung: Alfabeta.

Sugiyono. (2015). Metode Penelitian Kuantitatif Kualitatif R\&D. Bandung: Alfabeta.

Supomo, B., \& Indrianto, N. (2002). Metodologi Penelitian Bisnis, Edisi Pertama. BPFE.

Wahyuni, M., \& Sumarni. (2006). Metodologi Penelitian Bisnis. Yogyakarta: Andi Yogyakarta.

Zulfikar, R., \& Sari, J. (2014). Profesi Dan Profesionalisme Di Bidang IT. Jurnal Profesi Dan Profesionalisme. 